\title{
Novel Nitrogen Rich Polymers and Chitosan for Tissue Engineering of Intervertebral Discs
}

\author{
Fackson Mwale, $\mathrm{PhD}^{1, \mathrm{a}}$, Michael R.Wertheimer, Ph.D $\mathrm{D}^{2, \mathrm{~b}}$ \\ and John Antoniou, M.D., Ph.D ${ }^{3, c}$ \\ ${ }^{1}$ Division of Orthopaedic Surgery, McGill University, and Lady Davis Institute for Medical Research, \\ 3755, Chemin de la Cote Ste-Catherine, Montreal, Quebec H3T 1E2, Canada \\ ${ }^{2}$ Department of Engineering Physics, École Polytechnique, Montreal, Quebec H3T 1J4, Canada \\ afmwale@Idi.jgh.mcgill.ca, ${ }^{b}$ michel.wertheimer@polymtl.ca, ${ }^{c}$ janton@orl.mcgill.ca
}

Keywords: mesenchymal stem cells, collagen, osteogenesis, plasma polymers, tissue engineering, intervertebral discs

\begin{abstract}
Degenerative disc disease has been implicated as a major component of spine pathology. However, though biological repair of the degenerate disc would be the ideal treatment, there is a lack of a universally accepted scaffold for tissue engineering of intervertebral discs (IVD) and little is known of how to differentiate mesenchymal stem cells (MSCs) to a disc-like phenotype. We show that $2.5 \%$ Protasan ${ }^{\circledR}$ UP G213 cross-linked to 5\% genipin might be a promising scaffold for disc tissue engineering. Furthermore, we have developed extremely N-rich plasma polymer layers, which we call "PPE:N" (N-doped plasma-polymerized ethylene, containing up to $36 \%[\mathrm{~N}]$ ). We show that PPE:N almost completely suppresses the expression not only of type X collagen, but also of osteogenic marker genes such as alkaline phosphatase (ALP), bone sialoprotein (BSP) and osteocalcin (OC). In contrast, neither aggrecan nor types 1 collagen expression were significantly affected. These results indicate that PPE: N coatings may be suitable surfaces for inducing MSCs to a chondrocyte or disc-like phenotype for tissue engineering of cartilage or IVDs, in which hypertrophy and osteogenesis are suppressed.
\end{abstract}

\section{Introduction}

Low back pain is one of the most frequent health problems that, by age 70 , affect about $60 \%$ of the population [1]. Although the etiology of low back pain is often unclear, it is believed that intervertebral disc (IVD) degeneration plays a major role [2]. The present management of disc pathology has been focused on the symptoms associated with disc degeneration, and while surgical procedures produce a good short-term clinical result in the relief of pain, they alter the biomechanics of the spine and can lead to further degeneration of surrounding tissue and discs at adjacent levels $[3,4]$. In addition, the failure rate for lumbar fusions is $20 \%$ to $40 \%$ after five years [5].

Recent advances in tissue engineering offer the unique opportunity to engineer a replacement nucleus pulposus (NP) using polymer-cell constructs and growth factors. In the current studies, we sought to use chitosan salts cross-linked to genipin for NP supplementation via injection, rather than in vitro engineering of intact NP for implantation. This is a much simpler and technically more feasible proposition than attempting to engineer an entire disc.

Chitosan, an amino-polysaccharide obtained by the alkaline deacetylation of chitin, derived from crustacean shells, is currently being investigated for many pharmaceutical applications [6-8]. It is also important to prepare a cross-linked hydrogel, since this will decrease biodegradability and allow entrapped cells to synthesize a functional extracellular matrix before the polymer dissolves. Recently, it was discovered that chitosan could be cross-linked with a naturally occurring crosslinking reagent, genipin, which has been used in herbal medicine and in the production of food dyes 
$[9,10]$. In the current study, we demonstrate that $2.5 \%$ Protasan ${ }^{\circledR}$ UP G213 cross-linked to 5\% genipin is the best candidate for this purpose.

Mesenchymal stem cells (MSCs) are present in a variety of tissues during human development, and in adults they are prevalent in bone marrow. MSCs can be isolated, expanded in culture, and stimulated to differentiate into bone, cartilage, muscle, marrow stroma, tendon, fat and a variety of other connective tissues [11]. The study of these cells provides the basis for tissue engineering. Bone and cartilage formation involve the differentiation of MSCs to a specific and distinctive phenotypic pathway [12].

However, recent evidence indicates that a major drawback of current cartilage or IVD tissue engineering is that human MSCs rapidly express type X collagen [13,14] - a marker of chondrocyte hypertrophy associated with endochondral ossification $[15,16]$. In particular, MSCs obtained from the femoral intramedullary canal of osteoarthritis/rheumatoid arthritis patients (60-80 years old) rapidly express type X collagen [14]. Some studies have attempted to use growth factors to inhibit type X collagen expression [17] and osteogenic marker genes; however, little work has been done to investigate the effect of material surfaces on stem cell differentiation. It has been known for some time that cells may be sensitive to subtle differences in surface chemistry [18-22]. The nature of the surface can directly influence cellular responses [14,19,23,24], ultimately affecting the rate and quality of new tissue formation $[19,25]$. Previous studies have shown that contact with vitronectin and collagen I promotes the osteogenic differentiation of MSCs [24]. Furthermore, the creation of functional groups $\left(-\mathrm{CH}_{3},-\mathrm{NH}_{2}, \mathrm{SH},-\mathrm{OH}\right.$, and $\left.-\mathrm{COOH}\right)$ by silanization on glass surfaces was found to alter the differentiation potential of the human MSCs [22]. However, the mechanisms controlling human MSCs differentiation are not well understood. These studies suggest that extracellular matrix contact alone may be sufficient to induce stem cell differentiation.

We have recently developed an unique design of a "smart surface" with very high chemically-bound nitrogen concentration, $[\mathrm{N}]$, that we call "PPE:N" (N-doped plasma-polymerized ethylene) and that is capable of promoting cell adhesion [23]. In this study, we use this technology to elucidate the effect of three different PPE:N substrates with differing values of $[\mathrm{N}]$ on markers of hypertrophy and osteogenesis. Markers of chondrogenesis include collagen type II and aggrecan, with collagen type $\mathrm{X}$ being used as a marker of late-stage chondrocyte hypertrophy (associated with endochondral ossification) [16,26]. Osteogenic markers include alkaline phosphatase (ALP) [27], bone sialoprotein (BSP) [27,28], osteocalcin (OC) [27,28] and RUNX2 [29,30]. The findings we present indicate that the type of substrate used can influence cellular processes, particularly stem cell differentiation.

\section{Materials and Methods}

Deposition of PPE:N. PPE:N films were deposited on biaxially oriented polypropylene (BOPP) as previously described [23,31]. The characteristics of this $50 \mu \mathrm{m}$ thick isotactic polymer film, graciously provided by $3 \mathrm{M}$ Company, have also been described elsewhere $[32,33]$. The atmospheric pressure plasma deposition system comprised a moveable aluminium plate electrode, on which flat sheets of BOPP were uniformly coated in a $10 \mathrm{kHz}$, high voltage (HV, $18 \mathrm{kV}$ peakto-peak) dielectric barrier discharge (DBD) [23]. This was accomplished by carefully-controlled linear displacement of the substrate through the ca. $1 \mathrm{~cm}$ wide discharge zone between the cylindrical, ceramic-coated HV electrode and the grounded aluminum plate. Using this apparatus, films containing high and controllable total nitrogen content, [N], (see Eq. 1 below) were deposited from the precursor gas mixture composed of nitrogen $\left(\mathrm{N}_{2}, 10\right.$ standard liters per minute, slm) and ethylene $\left(\mathrm{C}_{2} \mathrm{H}_{4}\right.$, from 10 to 60 standard cubic centimeters per minute, $\left.\mathrm{sccm}\right)$.

PPE:N films with different nitrogen concentrations, [N], were studied and compared, knowing that changing [N] values can lead to significantly different cell responses [23]. Changing the flow rate of the ethylene gas precursor, $\mathrm{F}_{\mathrm{C} 2 \mathrm{H} 4}$, from the lowest value of $5 \mathrm{sccm}$ to higher values up to $60 \mathrm{sccm}$ gradually reduces [N], all other deposition conditions of course being maintained constant. Thus, for $\mathrm{F}_{\mathrm{C} 2 \mathrm{H} 4}=5 \mathrm{sccm},[\mathrm{N}] \approx 36 \%$, for $\mathrm{F}_{\mathrm{C} 2 \mathrm{H} 4}=10 \mathrm{sccm},[\mathrm{N}] \approx 29.5$, while for the highest $\mathrm{F}_{\mathrm{C} 2 \mathrm{H} 4}$ value used here, $20 \mathrm{sccm},[\mathrm{N}] \approx 25 \%$. These surfaces are thereafter designated 
respectively S5, S10, and S20. The surface compositions of PPE:N films were determined by X-ray photoelectron spectroscopy (XPS) [23,33]; throughout this article, we will be referring to their surface elemental concentrations, $[X]$, in terms of the elements that comprise PPE:N, namely $\mathrm{N}, \mathrm{C}$ and $\mathrm{O}$; since hydrogen cannot be detected by XPS, $[X]$ is given by:

$$
[X]=\frac{X}{N+C+O} \times 100 \%
$$

$\mathrm{N}, \mathrm{O}$ and $\mathrm{C}$ being determined from XPS broad-scan spectra [23,33]. Other characterisation methods used for PPE:N films included attenuated total internal reflectance FTIR (ATR-FTIR), contact angle goniometry (CAG), atomic force microscopy (AFM), stylus profilometry and spectroscopic ellipsometry, as described elsewhere [23].

Source and preparation of stem cells. MSCs were obtained from $15 \mathrm{ml}$ aspirates from the intramedullary canal of donors (60-80 years of age) undergoing total hip replacement for osteoarthritis using a protocol approved by the Research Ethics Committee of the Jewish General Hospital (Fig. 1, "Steps 1 and 2").. Bone marrow aspirates were processed essentially as previously described $[14,31,34]$.

Cell culture. One million of 3 or 4 passage MSCs were cultured on each of the three different PPE:N coatings on BOPP, in DMEM + 10\%FBS (Fig. 1, "Step 4"). Commercial polystyrene (PS) tissue culture dishes (Sarstedt Inc., Montreal, QC, Canada) were used as controls. The medium was changed every 2 days for up to 14 days, after which cells were harvested at different times or at the endpoint for gene expression studies.

Total RNA isolation. Total RNA was extracted from MSCs by a modification of the method of Chomcynski and Sacchi [35] using TRIzol reagent (Invitrogen, Burlington ON, Canada) as previously described [31].

Reverse transcription (RT) and polymerase chain reaction (PCR). The RT reaction was performed using $0.5 \mu \mathrm{g}$ total RNA isolated from the MSCs in a total volume of $20 \mu 1$, containing $50 \mathrm{mM}$ Tris- $\mathrm{HCl}$ (pH 8.3), $75 \mathrm{mM} \mathrm{KCl,} 3 \mathrm{mM} \mathrm{MgCl} 2,10 \mathrm{mM}$ dithiothreitol (DTT), $50 \mu \mathrm{M}$ each 2'-deoxy-adenosine-5'triphosphate (dATP), 2'-deoxy-guanosine-5'triphosphate (dGTP), 2'-deoxycytidine-5'triphosphate (dCTP) and 2'-deoxythymidine-5'triphosphate (dTTP), and 200 units of Superscript II - RNAse H'reverse transcriptase (Invitrogen).

PCR was performed in a total volume of $25 \mu 1$ containing: $10 \mathrm{mM}$ Tris- $\mathrm{HCl}(\mathrm{pH} \mathrm{8.3)}, 1.5$ $\mathrm{mM} \mathrm{MgCl} 2,0.4 \mathrm{mM}$ of dATP, dGTP, dCTP, dTTP, $0.8 \mu \mathrm{M}$ of each primer, $1 \mu \mathrm{l}$ of RT mixture and 2.5 units of Taq DNA polymerase (Invitrogen). The 35 cycles of PCR included denaturation $\left(94^{\circ} \mathrm{C}\right.$, $1 \mathrm{~min} 30 \mathrm{sec})$, annealing $\left(60^{\circ} \mathrm{C}, 45 \mathrm{sec}\right)$ and extension $\left(72^{\circ} \mathrm{C}, 7 \mathrm{~min}\right)$. After agarose $(1.6 \%)$ gel electrophoresis, PCR products were visualized by ethidium bromide staining and analyzed using the Bio-Rad VersaDoc image analysis system, equipped with a cooled CCD 12 bit camera (Bio-Rad Laboratories, Mississauga ON, Canada). Glyceraldehyde-3-phosphate dehydrogenase (GAPDH) was used as reference for gel loading. To confirm the lack of chromosomal DNA contamination of RNA samples, PCR was also performed with RNA aliquots. After confirming that there was no band detected that indicates contamination of the DNA, we proceeded with the experiments.

The primer sequences used were previously described and chosen because they are specific for human RNA and they amplify a single product [14,31]. GAPDH primers have been described in one of our earlier articles [14].

Statistical analysis. All experiments were performed in triplicates. Statistical differences between the treated and the control were analyzed by Statview (SAS Institute Inc.) for each culture time. Results were considered statistically significant at $\mathrm{P}<0.05$. All results are the average of three samples \pm standard deviation.

Preparation of genipin cross-linked chitosan. Ultra pure medical grade water soluble chitosan glutamate Protasan ${ }^{\circledR}$ UP G213 was obtained from FMC Biopolymer A.S. (Oslo, Norway). The chitosan glutamate $\mathrm{G} 213\left(\mathrm{M}_{\mathrm{W}} 300 \mathrm{kDa}\right)$ was $85 \%$ deacetylated. Protasan ${ }^{\circledR}$ ultra pure medical 
grades have been shown to be nontoxic [36,37]. 2.5\% Protasan ${ }^{\circledR}$ solution $(\mathrm{w} / \mathrm{v})$ was prepared in serum-free medium (DMEM $+100 \mu \mathrm{g} / \mathrm{ml}$ streptomycin $+100 \mathrm{U} / \mathrm{ml}$ penicillin (Hyclone, Logan, $\mathrm{UT}$, USA) $+50 \mathrm{ng} / \mathrm{ml}$ gentamicin, $\mathrm{pH}$ 7.4) at room temperature or at $37^{\circ} \mathrm{C}$, and cross-linked with $5 \%\left(\mathrm{w} / \mathrm{w}\right.$ Protasan $\left.{ }^{\circledR}\right)$ genipin (Challenge Bioproducts Co., Taiwan) as previously described [31]. The powders were added progressively to the medium under stirring, and mixing was continued for $1 \mathrm{~h}$ until the chitosan was completely dissolved. Subsequently, genipin powder was added to the chitosan solution.

Source of intervertebral discs. Adult bovine tails (2-4 years old) were obtained from Les Abattoirs Corbex Inc. (QC, Canada). All IVDs were classified as nondegenerate grade I according to the grading system of Thomson [38].

Cell isolation. Cells were isolated immediately after transportation from the abattoir. The IVDs were dissected from their adjacent vertebral bodies, placed in DMEM-high glucose (Hyclone), with $20 \mathrm{mM}$ HEPES, and $45 \mathrm{mM} \mathrm{NaHCO}_{3}, \mathrm{pH} 7.4$, containing $150 \mathrm{ng} / \mathrm{ml}$ gentamicin, $100 \mathrm{U} / \mathrm{ml}$ penicillin, $100 \mu \mathrm{g} / \mathrm{ml}$ streptomycin, and $0.25 \mu \mathrm{g} / \mathrm{ml}$ fungizone (medium A) (InVitrogen). Under aseptic conditions, the IVDs were separated by dissection into regions corresponding to the annulus fibrosus (AF) and the nucleus pulposus (NP). The AF and NP were dissected into approximately $2 \mathrm{~mm}$ fragments and were washed twice in medium A for 15 minutes. Cells were enzymatically isolated from the tissue using a sequential protease type XIV/collagenase protocol [39]. Briefly, $28 \mathrm{~g}$ and $10 \mathrm{~g}$ of $\mathrm{AF}$ and NP tissues, respectively, were incubated at $37^{\circ} \mathrm{C}$ with stiring (75 rpm) for $1 \mathrm{~h}$ in medium A with bacterial protease type XIV (Sigma-Aldrich, Oakville, ON, Canada) at $0.2 \%(\mathrm{w} / \mathrm{v})$ for the NP and $0.4 \%(\mathrm{w} / \mathrm{v})$ for the AF. The tissue was then washed and a second digestion was performed overnight at $37^{\circ} \mathrm{C}$ in washing medium (medium A without gentamicin and fungizone) supplemented with 10\% fetal bovine serum (FBS) (Hyclone) and bacterial collagenase type IA (Sigma-Aldrich) at $0.03 \%(\mathrm{w} / \mathrm{v})$ for the NP and $0.06 \%(\mathrm{w} / \mathrm{v})$ for the AF. The resulting cell suspensions were passed through a $70-\mu \mathrm{m}$ cell strainer (BD Biosciences, Mississauga, ON, Canada), washed twice in washing medium containing $10 \%$ FBS, and cells were recovered by centrifugation at $400 \mathrm{xg}$ for $6 \mathrm{~min}$. Cells were counted with a hemacytometer and the viability was determined using $0.04 \%$ Trypan Blue Dye. Approximately $15 \times 10^{6}$ cells were recovered from $28 \mathrm{~g}$ of AF per tail and $5 \times 10^{6}$ cells from $10 \mathrm{~g}$ of the NP per tail.

Entrapment and culture of disc cells in scaffold. Disc cells were entrapped in the chitosan/genipin solution at room temperature as previously described [31].

Injectability in human IVD. Whole human lumbar spine specimens were removed from fresh cadavers, aged 60 to 65 . Thomson grading was performed as previously described [40,41]. A solution of $2.5 \%$ Protasan ${ }^{\circledR}$ UP G213 and 5\% genipin was used to examine how the solution distributes into the clefts of degenerated discs following injection. Coomassie blue was added to the chitosan/genipin mixture to facilitate visualization of the gel. Each injection was $0.2 \mathrm{ml}$ and was performed through an $18 \mathrm{G}$ needle. Gelling was achieved at room temperature within about $30 \mathrm{~min}$.

\section{Results and Discusion}

Over the past 5 years, we have conducted studies aimed at characterizing and differentiating MSCs from osteoarthritic (OA) patients to a disc- or cartilage-like phenotype, because these cells are of greater clinical relevance than those from normal adults [14,23,31,42-45]. OA patients are the ones who will require a source of autologous stem cells, if biological repair of their cartilage lesions is to be a therapeutic option and if immuno-rejection and possible infection are to be avoided. However, our studies indicated that a major drawback for current cartilage- and IVD-tissue engineering is that those cells express type $\mathrm{X}$ collagen (a marker of chondrocyte hypertrophy associated with endochondral ossification) and osteogenic markers that suggest a commitment to bone formation $[14,31,44,46]$. This is a problem, since stem cells must be uncommitted in order to differentiate to chondrocytes or disc-like cells. Some studies attempted to use growth factors (like PTHrP) to inhibit type X collagen expression [47], but none had addressed the effect of the substrate's chemical composition on chondrocyte hypertrophy and osteogenesis. 
Novel methods of suppressing hypertrophy and osteogenesis of MSCs from OA patients (Fig. 1, “Step 3"). As pointed out above, MSCs from OA patients must first be dedifferentiated (by suppressing type X collagen and osteogenic marker genes) before differentiating them to disc cells, as bone is evidently not desired in the IVD. Our early studies showed that Nfunctionalized polypropylene and Nylon ${ }^{\mathrm{TM}}$ almost completely inhibited type X collagen expression in MSCs [14,44]. More recently, we cultured human MSCs on PPE:N [31], which showed that this surface completely suppresses the expression not only of type X collagen, but also of osteogenic marker genes, such as bone sialoprotein (Fig. 2). These results therefore indicated that PPE:N coatings may be suitable surfaces for inducing MSCs to a chondrocyte or disc-like phenotype, in which hypertrophy and osteogenesis are suppressed.

Substrates for cell growth: Plasma-assisted surface modification and deposition of thin films (Fig. 1, “Step 3"). As discussed by Freshney [48], cells may be made to grow on many different charged surfaces, usually polymers. However, natural and synthetic polymers are characterised by low surface tension, which impedes "wetting" by physiological fluids and the adhesion of living cells. Nevertheless, polymer surfaces can become hydrophilic and cell-adherent when new functional (polar) groups are created on them, a modification that is usually accomplished by exposure to electrical discharge plasmas [49]. There exist commercial cell-culture surfaces, for example "CellBIND" ${ }^{\mathrm{TM}}$ " (Corning) and "Primaria" ${ }^{\mathrm{TM}}$ " (Becton-Dickinson), both of which are plasma-modified polystyrene. While CellBIND ${ }^{\mathrm{TM}}$ possesses negatively-charged oxidized functionalities, Primaria ${ }^{\mathrm{TM}}$ is claimed to have both the former and positively-charged nitrogencontaining (amine) sites. In earlier work, described above, we performed cell cultures on commodity polymers that had been modified by plasmas in nitrogen, ammonia $\left(\mathrm{NH}_{3}\right)$, and oxygen, treatments that create various polar functional groups on the polymer surfaces, for example amines, nitriles, amides, hydroxyls, carboxyls, etc. [49]. However, as also reported by other authors [50,51], we found that primary amines $\left(\mathrm{R}^{-\mathrm{NH}_{2}}\right)$ appear to be the functionality "preferred" by many celltypes. But even though polymer surface modification by plasma is convenient and advantageous in many ways, it has several shortcomings: (i) difficulty to attain high hetero-atom concentrations, $[\mathrm{X}],(\mathrm{X}=\mathrm{O}$ or $\mathrm{N})$; (ii) decay of $[\mathrm{X}]$ with prolonged storage time, on account of "reptational" motion of near-surface macromolecules; (iii) difficulty to obtain highly-specific surface functionality, for example $\mathrm{R}-\mathrm{NH}_{2}$ groups. We have found that these drawbacks can be overcome by plasma polymerization [52]: We recently reported "tailored" surface coatings that we call "PPE:N", $\mathrm{N}$-doped plasma-polymerized ethylene, and that contain up to $36 \%[\mathrm{~N}]$; they overcome all three shortcomings listed above and possess, in addition, other important characteristics such as the inhibition of hypertrophy and osteogenesis in MSCs [31]. Furthermore, since we discovered that some cell types do not adhere to modified surfaces unless $[\mathrm{N}]$ exceeds certain high "critical" values, $[\mathrm{N}]_{\text {crit }}$, plasma polymerization offers the only alternative in such cases.

Tethering transforming growth factor beta (Fig. 1, “Step 5"). Continuing from above, it is unlikely that cells attach directly to synthetic polymer substrates; more likely, it is the matrix products secreted by the cells that adhere to the substrate and provide ligands for the interaction of matrix receptors [48]. It is in this sense that we will use PPE:N in future to tether suitable biomolecules such as TGF- $\beta$ for stem cell differentiate stem cells to an NP-like phenotype. Studies of TGF- $\beta$ isoforms (TGF- $\beta 1,-\beta 2$ and $-\beta 3$ ) interactions with their biological partners has demonstrated that TGF- $\beta$, when covalently immobilized at the surface of a biosensor, is still able to interact with its receptor ectodomains [53]. This strongly suggests that covalent grafting of TGF- $\beta 1$ on PPE:N will not impede its interactions with cell surface receptors, nor subsequent signalling.

Studies on Link N (Fig. 1, “Step 5”). Link N is the amino-terminal peptide of link protein (DHLSDNYTLDHDRAIH) which is generated by the cleavage of human link protein by stromelysins 1 and 2, gelatinase A and B, and collagenase between His(16) and Ile(17). It undergoes proteolytic degradation with aging. We have shown that this peptide stimulates both proteoglycans and collagens II and IX in adult IVD cells [39]. Thus, Link N represents a potential growth factor able to stimulate the extracellular matrix proteins of an NP-like phenotype. We 
believe that culturing dedifferentiated stem cells on PPE:N with TGF- $\beta 1$ and link $N$ would drive stem cells to an NP- like phenotype while avoiding hypertrophy.

Studies on scaffolds (Fig. 1, “Step 8”, “Step 9", and "Step 10"). Over the past 3 years we have conducted studies aimed at developing a scaffold for tissue engineering of the IVD, as none are currently universally accepted. Since we wished to develop a scaffold able to retain matrix molecules and to allow implantation without major disruption of the $\mathrm{AF}$, we chose one based on chitosan $[43,45]$. This scaffold is injectable (very soluble at room temperature, but it gels at $37^{\circ} \mathrm{C}$ ), biocompatible, and it can retain more than $80 \%$ of the proteoglycan and collagen produced by entrapped cells [43]. Most importantly, when injected into the degenerated NP of human cadaveric IVD, the gel flowed into the clefts without leakage [45].

In conclusion, our results suggest that PPE: $\mathrm{N}$ coatings may be suitable surfaces for inducing MSCs to a chondrocyte or disc-like phenotype for tissue engineering of cartilage or IVDs and that chitosan cross-linked to genipin might be a promising scaffold for disc tissue engineering.

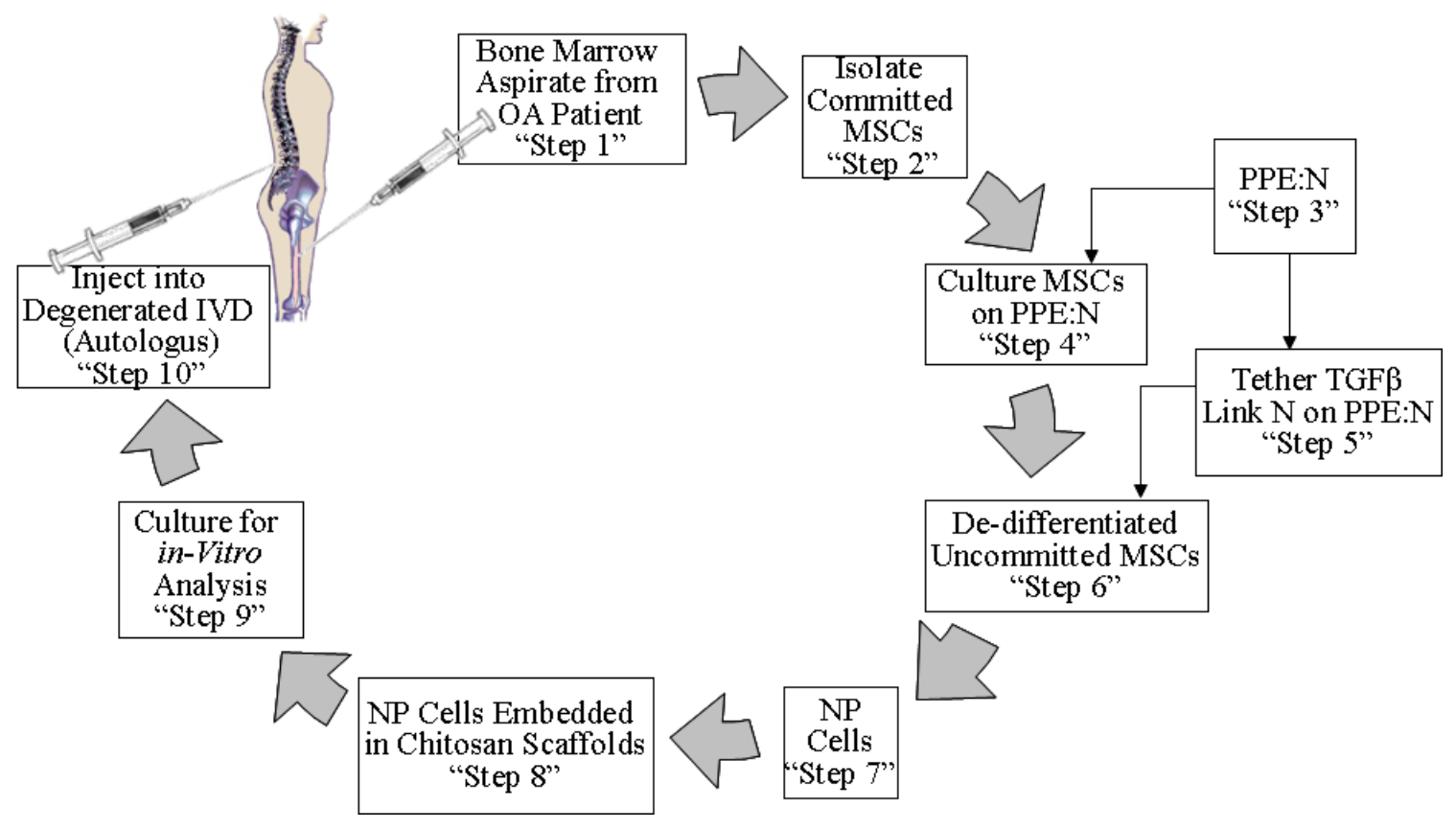

Fig. 1. Schematic flow-chart representation of the long term goal of the research using autologous MSCs from OA patients to repair degenerated IVDs. Steps numbered "1" to "10"are referenced in paragraph headings and in the text.
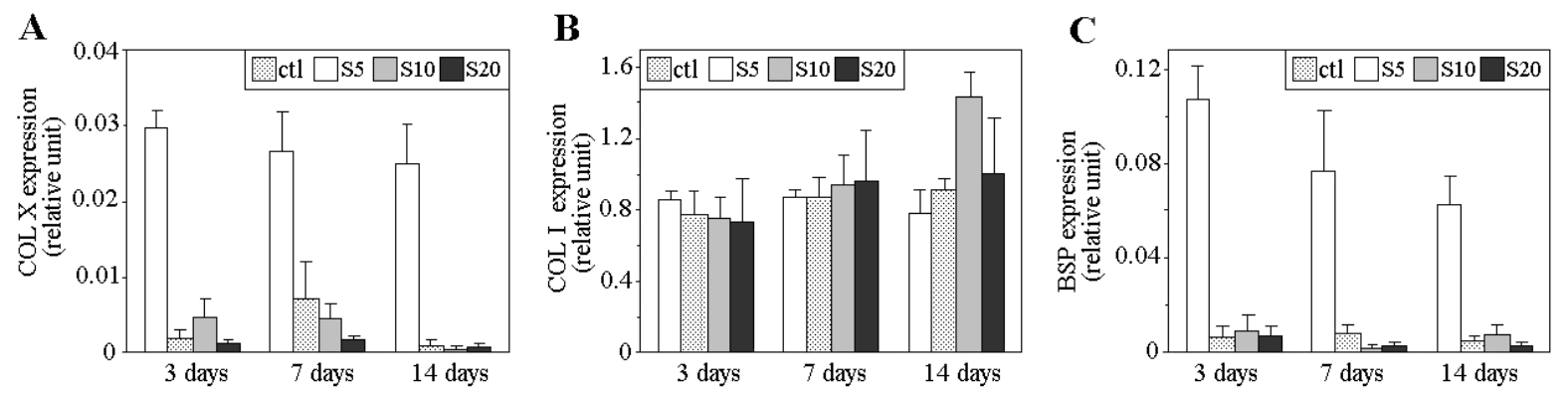

Fig. 2. Gene expression in MSCs cultured on PPE:N surfaces. A) type X collagen (Col X); B) type I collagen (Col I); C) Bone sialoprotein (BSP). Ctl refers to cells cultured on control surfaces. 


\section{Acknowledgements}

This research was supported by grants from the Canadian Institute of Health Research (CIHR), North American Spine Society (NASS), and AO Foundation (Switzerland) (to F.M and J.A). We thank Dr. Alain Petit and Ms. Laura Epure for their help in preparing the manuscript.

\section{References}

[1] F. Biering-Sorensen: Dan. Med. Bull. Vol. 29 (1982), p. 289.

[2] K. Luoma, H. Riihimaki, R. Luukkonen, R. Raininko, E. Viikari-Juntura and A. Lamminen: Spine Vol. 25 (2000), p. 487.

[3] C.G. Hutter: Clin. Orthop. Rel. Res. Vol. 179 (1983), p. 86.

[4] F.M. Phillips, J. Reuben and F.T. Wetzel: J. Bone Joint Surg. Br. Vol. 84-B (2002), p. 289.

[5] R.K. Snider, N.K. Krumwiede, L.J. Snider, J.M. Jurist, R.A. Lew and J.N. Katz: J. Spinal Disord. Vol. 12 (1999), p. 107.

[6] T. Chandy and C.P. Sharma: Biomaterials Vol. 14 (1993), p. 939.

[7] L. Illum: Pharm. Res. Vol. 15 (1998), p. 1326.

[8] L. Illum, I. Jabbal-Gill, M. Hinchcliffe, A.N. Fisher and S.S. Davis: Adv. Drug. Deliv. Rev. Vol. 51 (2001), p. 81.

[9] F.L. Mi, Y.C. Tan, H.C. Liang, R.N. Huang and H.W. Sung: J. Biomater. Sci. Polym. Ed. Vol. 12 (2001), p. 835.

[10]F.L. Mi, Y.C. Tan, H.F. Liang and H.W. Sung: Biomaterials Vol. 23 (2002), p. 181.

[11] A.I. Caplan and S.P. Bruder: Trends Mol. Med. Vol. 7 (2001), p. 259.

[12] A.I. Caplan: J. Orthop. Res. Vol. 9 (1991), p. 641.

[13]F. Barry, R.E. Boynton, B. Liu and J.M. Murphy: Exp. Cell. Res. Vol. 268 (2001), p. 189.

[14] V. Nelea, L. Luo, C.N. Demers, J. Antoniou, A. Petit, S. Lerouge, M.R. Wertheimer and F. Mwale: J. Biomed. Mater. Res. A Vol. 75A (2005), p. 216.

[15]F. Mwale, E. Tchetina, C.W. Wu and A.R. Poole: J. Bone Miner. Res. Vol. 17 (2002), p. 275.

[16] A.R. Poole, S. Laverty and F. Mwale: The Osteoporosis Primer (Cambridge University Press, New York, 2000).

[17] A. Steinert, M. Weber, A. Dimmler, C. Julius, N. Schutze, U. Noth, H. Cramer, J. Eulert, U. Zimmermann and C. Hendrich: J. Orthop. Res. Vol. 21 (2003), p. 1090.

[18] T.O. Acarturk, M.M. Peel, P. Petrosko, W. LaFramboise, P.C. Johnson and P.A. DiMilla: J Biomed. Mater. Res. Vol. 44 (1999), p. 355.

[19] B.D. Boyan, T.W. Hummert, D.D. Dean and Z. Schwartz: Biomaterials Vol. 17 (1996), p. 137.

[20] S. Britland, P. Clark, P. Connolly and G. Moores: Exp. Cell Res. Vol. 198 (1992), p. 124.

[21] Y. Hu, S.R. Winn, I. Krajbich and J.O. Hollinger: J. Biomed. Mater. Res. Vol. 64A (2003), p. 583.

[22] J.M. Curran, R. Chen and J.A. Hunt: Biomaterials Vol. 26 (2005), p. 7057.

[23] P.L. Girard-Lauriault, F. Mwale, M. Iordanova, C.N. Demers, P. Desjardins and M.R. Wertheimer: Plasma Processes \& Polym. Vol. 2 (2005), p. 263.

[24] R.M. Salasznyk, W.A. Williams, A. Boskey, A. Batorsky and G.E. Plopper: J. Biomed. Biotechnol. Vol. 2004 (2004), p. 24.

[25] W.J. Li, R. Tuli, X. Huang, P. Laquerriere and R.S. Tuan: Biomaterials Vol. 26 (2005), p. 5158.

[26]F. Mwale, C. Billinghurst, W. Wu, M. Alini, C. Webber, A. Reiner, M. Ionescu, J. Poole and A.R. Poole: Dev. Dyn. Vol. 218 (2000), p. 648.

[27] J.E. Aubin: J. Cell Biochem. Vol. 72 (1999), p. 396.

[28] N.I. zur Nieden, G. Kempka and H.J. Ahr: Differentiation Vol. 71 (2003), p. 18.

[29] G.S. Stein, J.B. Lian, A.J. van Wijnen, J.L. Stein, M. Montecino, A. Javed, S.K. Zaidi, D.W. Young, J.Y. Choi and S.M. Pockwinse: Oncogene Vol. 23 (2004), p. 4315.

[30] J.B. Lian and G.S. Stein: Curr. Pharm. Des. Vol. 9 (2003), p. 2677. 
[31]F. Mwale, P.L. Girard-Lauriault, H.T. Wang, S. Lerouge, J. Antoniou and M.R. Wertheimer: Tissue Eng. Vol. 12 (2006), p. 2639.

[32] N.A. Bullett, D.P. Bullett, F. Truica-Marasecu, S. Lerouge, F. Mwale and M.R. Wertheimer: Appl. Surf. Sci. Vol. 235 (2004), p. 395.

[33] S. Guimond, I. Radu, G. Czeremuszkin, D.J. Carlsson and M.R. Wertheimer: Plasmas \& Polym. Vol. 7 (2002), p. 71.

[34] D.C. Colter, R. Class, C.M. DiGirolamo and D.J. Prockop: Proc. Natl. Acad. Sci. U.S.A. Vol. 97 (2000), p. 3213.

[35] P. Chomczynski and N. Sacchi: Anal Biochem. Vol. 162 (1987), p. 156.

[36] A. Chenite, C. Chaput, D. Wang, C. Combes, M.D. Buschmann, C.D. Hoemann, J.C. Leroux, B.L. Atkinson, F. Binette and A. Selmani: Biomaterials Vol. 21 (2000), p. 2155.

[37] G. Molinaro, J.C. Leroux, J. Damas and A. Adam: Biomaterials Vol. 23 (2002), p. 2717.

[38] J.P. Thompson, R.H. Pearce, M.T. Schechter, M.E. Adams, I.K. Tsang and P.B. Bishop: Spine Vol. 15 (1990), p. 411.

[39]F. Mwale, C.N. Demers, A. Petit, P. Roughley, A.R. Poole, T. Steffen, M. Aebi, and J. Antoniou: J. Cell Biochem. Vol. 88 (2003), p. 1202.

[40] J. Antoniou, T. Steffen, F. Nelson, N. Winterbottom, A.P. Hollander, R.A. Poole, M. Aebi and M. Alini: J. Clin. Invest. Vol. 98 (1996), p. 996.

[41] J. Antoniou, N.M. Goudsouzian, T.F. Heathfield, N. Winterbottom, T. Steffen, A.R. Poole, M. Aebi and M. Alini: Spine Vol. 21 (1996), p. 1153.

[42]F. Mwale, H.T. Wang, A. Petit, P.L. Girard-Lauriault, C.J. Hunter, J.A. Ouellet, M.R. Wertheimer and J. Antoniou: Biomed. Eng. Online Vol.6 (2007), p. 33.

[43] P. Roughley, C. Hoemann, E. Desrosiers, F. Mwale, J. Antoniou and M. Alini: Biomaterials Vol. 27 (2006), p. 388

[44]F. Mwale, H.T. Wang, V. Nelea, L. Luo, J. Antoniou and M.R. Wertheimer: Biomaterials Vol. 27 (2006), p. 2258.

[45]F. Mwale, M. Iordanova, C.N. Demers, T. Steffen, P. Roughley and J. Antoniou: Tissue Eng. Vol. 11 (2005), p. 130.

[46]F. Mwale, D. Stachura, P. Roughley and J. Antoniou: J. Orthop. Res. Vol. 24 (2006), p. 1791.

[47] W. Kafienah, S. Mistry, S.C. Dickinson, T.J. Sims, I. Learmonth and A.P. Hollander: Arthritis Rheum. Vol. 56 (2007), p. 177.

[48] R.I. Freshney: Culture of Cells for Tissue Engineering (J. Wiley \& Sons Inc., New York, 2006).

[49] M.R. Wertheimer, L. Martinu, J.E. Klemberg-Sapieha and G. Czeremuszkin: Adhesion Promotion Techniques in Advanced Technologies (Marcel Dekker, New York, 1998).

[50]K.H. Siow, L. Britcher, S. Kumar and H.J. Griesser: Plasma Processes \& Polymers Vol. 3 (2006), p. 392.

[51] A. Meyer-Plath, K. Schröder, B. Finke and A. Ohl: Vacuum Vol. 71 (2003), p. 391.

[52] H.K. Yasuda: Polymerization (Academic Press, New York, 1985).

[53] G. De Crescenzo, S. Grothe, J. Zwaagstra, M. Tsang, and M.D. O'Connor-McCourt: J Biol. Chem. Vol. 276 (2001), p. 29632. 